\title{
AGE-DEPENDENT CHANGES IN BIOCHEMICAL COMPOSITION OF BLOOD IN GILTS FROM LARGE-SCALE PIGGERIES
}

\author{
A. HLOUŠEK \\ Department of Farm Animal Reproduction and Surgery, University of Veterinary Science, \\ 61242 Brno
}

Received October 26, 1977

\begin{abstract}
Hloušek A.: Age-dependent Changes in Biochemical Composition of Blood in Gilts from Large-scale Piggeries. Acta vet. Brno, 47, 1978: 15-21.

The biochemical composition of blood serum was examined in 75 gilts of 4-10 months and $30-120 \mathrm{~kg}$ body mass, divided in 5 groups according to age. Among the minerals determined, the youngest group showed the lowest calcium level of $5.9 \pm$ $\pm 0.61 \mathrm{mg} / 100 \mathrm{ml}$, and, the highest phosphorus level of $7.1 \pm 0.56 \mathrm{mg} / 100 \mathrm{ml}$. The lowest magnesium level was also found in group I., the highest in groups IV. and V. In gilts of group I., there was the lowest amount of vitamin A (16.2 \pm 4.8 $\mathrm{mcg} / 100 \mathrm{ml}$ ), older gilts had higher levels. The difference between groups I. and V. was statistically highly significant. The content of carbohydrates was constant in the entire course of growth, differring little from the content in blood of sows. There was slightly less bilirubin in blood of the growing gilts, the content of cholesterol was about the same in gilts and sows. The activity of enzymes studied varied considerably.
\end{abstract}

Gilts, blood serum, minerals, carbohydrates, vitamin A, bilirubin, cholesterol, enzymes.

In different periods of age, blood goes through physiological changes of its biochemical composition. Disposition for a good reproductive capacity of sows is formed in the periods of weaning, growth and maturing. Clinical methods of surveying the state of health in the course of these periods are insufficient, since the patological state detected this way is difficult to remedy. Consequently, laboratory examinations carried out in large-scale farming conditions are of increasing importance. They can signal defficiences in organism earlier than serious damage occurs, and, stimulate steps such as change of diet, supply of nutrients, minerals and vitamins a. s. o.

The majority of literature data refers to changes occurring in sows in different phases of their reproductive cycle: Kudláč et al. (1976), in puerperium, Bechyně (1974), Maclean (1972), Albritton (1952), Meier (1963), Nachreiner and Ginther (1972), Šulc and Bechyně (1975), in pregnancy, Herak et al. (1975), in sows after weaning. Concise data on blood values are also quoted in some handbooks and text-books, e. g. Azimov et al. (1958), Wirth (1952).

It was our goal to examine changes occurring in blood of Large White gilts in the course of their growth and development in large-scale piggeries, since no such examinations have been performed in these conditions.

\section{Material and Methods}

Examinations of biochemical blood composition were carried out in Large White gilts of different age and body mass, reared in windowless large-scale piggeries, fed three times a day the standard mixture PCH 1 up to $50 \mathrm{~kg}$ and KPB above $50 \mathrm{~kg} \mathrm{~b}$. m. Drinking water was freely accessible.

Five groups of 15 animals each were formed according to age and body mass of the gilts as follows: 

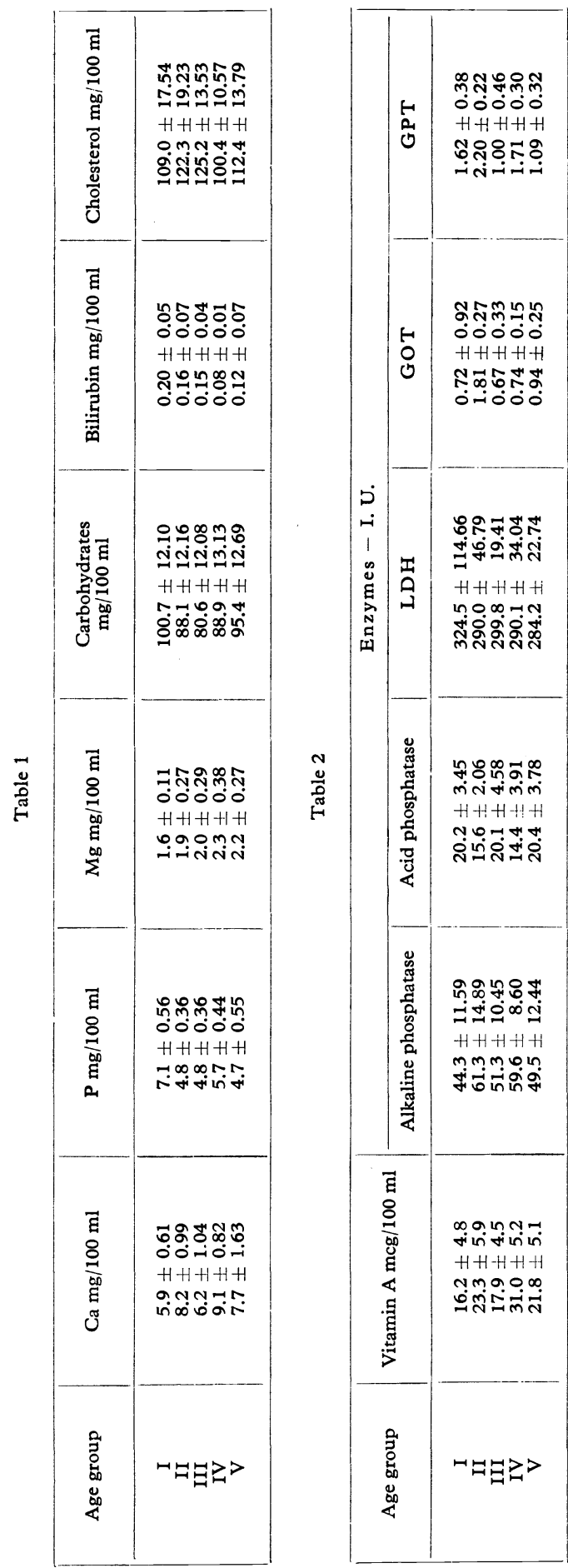

Group I:

Gilts aged 4-4.5 months, of $30-40 \mathrm{~kg}$ Group II:

Gilts aged 5-6 months, of $40-50 \mathrm{~kg}$ Group III :

Gilts aged 7-8 months, of $60-80 \mathrm{~kg}$, Group IV:

Gilts aged 8-9 months, of $80-95 \mathrm{~kg}$ Group V:

Gilts aged 9-10 months, of $95-120 \mathrm{~kg}$.

Blood samples from vena cava cranialis in group I., and from and ear vein punctured by scalpel in larger animals, were collected into tubes containing evaporation residue of Wintrobe's solution, and into test tubes to obtain blood serum. The blood samples were centrifuged immediately after collecting.

Calcium and magnesium levels were determined photocolorimetrically, using Bio-La-tests Lachema. The level of phosphorus was measured by Urbach and Rab's method (Homolka 1969). For photometrical determination of activity of enzymes under study, test produced by Boehringer or Lachema were used. The levels of carbohydrates were determined photocolorimetrically, using ortho-toluidine reagent. Bilirubin and cholesterol were determined photometrically with Bio-La-tests (Homolka 1969; Hořejší et al. 1964; Hořejší 1970).

Mean values and standard deviations were calculated, and, Student's $t$-test was used to evaluate statistical differences between each single group and the group of mature gilts (V.) Roth et al. (1962).

\section{Results}

Blood serum level of minerals:

Calcium: The youngest gilts had the lowest Ca level of $5.9 \pm 0.61$ $\mathrm{mg} / 100 \mathrm{ml}$, but, as soon as in the next group, the content of $\mathrm{Ca}$ rose and then kept elevated permanently. The highest calcium levels were observed in group IV. Differences were highly significant between groups I. and V., III. and V., IV. and V., while non-significant between groups II. and V.

Phosphorus: Results were reverse to those with calcium. From the highest value of $7.1 \pm 0.56$ 
$\mathrm{mg} / 100 \mathrm{ml}$ in group I., the level dropped to $4.7 \pm 0.57 \mathrm{mg} / 100 \mathrm{ml}$ in group V. Differences between groups I. and V., and IV. and V. were statistically highly significant, the rest was non-significant.

Magnesium: Lowest magnesium levels were in the youngest gilts $(1.6 \pm$ $\pm 1.1 \mathrm{mg} / 100 \mathrm{ml}$ in group I.), highest levels in groups IV. $2.3 \pm 0.38 \mathrm{mg} / 100 \mathrm{ml}$ ) and V. $(2.2 \pm 0.27 \mathrm{mg} / 100 \mathrm{ml})$. The difference between groups I. and V. was of high statistical significance, between groups II. and V. significant, the rest non-significant.

Blood carbohydrates: Highest levels were determined in the youngest group I. (100.7 $\pm 12.10 \mathrm{mg} / 100 \mathrm{ml})$. Lowest levels in the medium group III. $(80.6 \pm 12.08 \mathrm{mg} / 100 \mathrm{ml})$. Differences were not great, extreme values mutually overlapped. Highly significant was the difference between groups III. and IV., the rest was non-significant.

Bilirubin: In group I., the bilirubin level was $0.20 \pm 0.05 \mathrm{mg} / 100 \mathrm{ml}$. With increasing age, it dropped to $0.08 \pm 0.02 \mathrm{mg} / 100 \mathrm{ml}$ in group IV. Differences were highly significant between groups I. and. V., significant between groups IV. and V., non-significant with the rest.

Cholesterol: The mean level of cholesterol in blood serum of gilts ranged from 100.4 to $125.2 \mathrm{mg} / 100 \mathrm{ml}$. There were considerable individual variations and no relation to age or body mass could be established. Differences between groups were significant (III.-V., IV.-V.) or non-significant.

Vitamin A: The lowest content of vitamin A was in group I. $(16.2 \pm 4.8$ $\mathrm{mcg} / 100 \mathrm{ml})$, the highest in group IV. $(31.0 \pm 5.20 \mathrm{mcg} / 100 \mathrm{ml})$. The difference was highly significant between groups I. and V., significant between groups IV. and V., non-significant in the rest.

Enzymes:

It is obvious from Table 2 that the activity of enzymes studied (phosphatases, LDH, GOT, GPT) varied to a considerable extent.

Alkaline phosphatase: Lowest activity was determined in group I. In the rest of groups, the values were higher, but, the differences were just significant (II.-V., IV.-V.) or non-significant.

Table 1 a

Statistical evaluation of biochemical findings in blood serum of gilts

\begin{tabular}{|c|c|c|c|c|}
\hline \multirow{2}{*}{ Parameter } & \multicolumn{4}{|c|}{ Comparison between groups } \\
\hline & $\mathbf{I}-\mathbf{V}$ & II - V & III - V & IV - V \\
\hline Calcium & $\begin{array}{l}\text { increase } \\
P<0.01\end{array}$ & $\begin{array}{l}\text { decrease } \\
\text { nonsignificant }\end{array}$ & $\begin{array}{l}\text { increase } \\
P<0.01\end{array}$ & $\begin{array}{l}\text { decrease } \\
P<0.01\end{array}$ \\
\hline Phosphorus & $\begin{array}{l}\text { decrease } \\
P<0.01\end{array}$ & $\begin{array}{l}\text { decrease } \\
\text { nonsignificant }\end{array}$ & $\begin{array}{l}\text { decrease } \\
\text { nonsignificant }\end{array}$ & $\begin{array}{l}\text { decrease } \\
P<0.01\end{array}$ \\
\hline Magnesium & $\begin{array}{l}\text { increase } \\
P<0.01\end{array}$ & $\begin{array}{l}\text { increase } \\
P<0.05\end{array}$ & $\begin{array}{l}\text { decrease } \\
\text { nonsignificant }\end{array}$ & $\begin{array}{l}\text { decrease } \\
\text { nonsignificant }\end{array}$ \\
\hline Carbohydrates & $\begin{array}{l}\text { decrease } \\
\text { nonsignificant }\end{array}$ & $\begin{array}{l}\text { increase } \\
\text { nonsignificant }\end{array}$ & $\begin{array}{l}\text { increase } \\
P<0.01\end{array}$ & $\begin{array}{l}\text { increase } \\
\text { nonsignificant }\end{array}$ \\
\hline Bilirubin & $\begin{array}{l}\text { decrease } \\
P<0.01\end{array}$ & $\begin{array}{l}\text { decrease } \\
\text { nonsignificant }\end{array}$ & $\begin{array}{l}\text { decrease } \\
\text { nonsignificant }\end{array}$ & $\begin{array}{l}\text { increase } \\
P<0.05\end{array}$ \\
\hline Cholesterol & $\begin{array}{l}\text { increase } \\
\text { nonsignificant }\end{array}$ & $\begin{array}{l}\text { decrease } \\
\text { nonsignificant }\end{array}$ & $\begin{array}{l}\text { decrease } \\
P<0.05\end{array}$ & $\begin{array}{l}\text { increase } \\
P<0.05\end{array}$ \\
\hline
\end{tabular}


Table 2a

Statistical evaluation of vitamin $A$ and enzymes in blood serum of gilts

\begin{tabular}{|c|c|c|c|c|}
\hline \multirow{2}{*}{ Parameter } & \multicolumn{4}{|c|}{ Comparison between groups } \\
\hline & $\mathbf{I}-\mathbf{V}$ & II $-\mathbf{V}$ & III - V & IV - V \\
\hline Vitamin A & $\begin{array}{l}\text { increase } \\
P<0.01\end{array}$ & $\begin{array}{l}\text { decrease } \\
\text { nonsignificant }\end{array}$ & $\begin{array}{l}\text { increase } \\
P<0.05\end{array}$ & $\begin{array}{l}\text { decrease } \\
P<0.01\end{array}$ \\
\hline AF & $\begin{array}{l}\text { increase } \\
\text { nonsignificant }\end{array}$ & $\begin{array}{l}\text { decrease } \\
P<0.05\end{array}$ & $\begin{array}{l}\text { decrease } \\
\text { nonsignificant }\end{array}$ & $\begin{array}{l}\text { decrease } \\
P<0.05\end{array}$ \\
\hline KF & $\begin{array}{l}\text { increase } \\
\text { nonsignificant }\end{array}$ & $\begin{array}{l}\text { increase } \\
P<0.05\end{array}$ & $\begin{array}{l}\text { increase } \\
\text { nonsignificant }\end{array}$ & $\begin{array}{l}\text { increase } \\
P<0.01\end{array}$ \\
\hline LDH & $\begin{array}{l}\text { decrease } \\
\text { nonsignificant }\end{array}$ & $\begin{array}{l}\text { decrease } \\
\text { nonsignificant }\end{array}$ & $\begin{array}{l}\text { decrease } \\
\text { nonsignificant }\end{array}$ & $\begin{array}{l}\text { decrease } \\
\text { nonsignificant }\end{array}$ \\
\hline GOT & $\begin{array}{l}\text { increase } \\
\text { nonsignificant }\end{array}$ & $\begin{array}{l}\text { decrease } \\
P<0.01\end{array}$ & $\begin{array}{l}\text { increase } \\
P<0.05\end{array}$ & $\begin{array}{l}\text { increase } \\
P<0.05\end{array}$ \\
\hline GPT & $\begin{array}{l}\text { decrease } \\
P<0.01\end{array}$ & $\begin{array}{l}\text { decrease } \\
P<0.01\end{array}$ & $\begin{array}{l}\text { increase } \\
\text { nonsignificant }\end{array}$ & $\begin{array}{l}\text { decrease } \\
P<0.01\end{array}$ \\
\hline
\end{tabular}

Acid phosphatase: There was a statistically highly significant difference between groups IV. and V. (14.4 \pm 3.91$)$ and $20.4 \pm 3.78$, respectively). The difference between groups II. and V. was significant, the rest non-significant.

LDH: Changes in activity were small, differences non-significant. The highest values were in group I., the lowest in group V.

GOT: The highest activity of $1.81 \pm 0.27$ was determined in group II. There were considerable variations in GOT activity in the course of growth of gilts. Only the difference between groups II. and V. was of high statistical significance.

GPT: The activity of this enzyme was evidently higher during the first months (1.62 \pm 0.38 in group I., and $2.20 \pm 0.22$ in group II.). Differences were highly significant between groups I. and V., II. and V., IV. and V. Non-significant was the difference between groups III. and V.

\section{Discussion}

Our results showing slightly lower calcium levels in young gilts are in agreement with literature data. Hackel et al. (1960), found such levels even in sows aged 1-2 years. The low level of calcium is connected with elevated requirement during the period of growth, and is even lower than in sows in puerperial period, where Kudláč et al. (1976), ascertained the mean value of $9.07 \mathrm{mg} / 100 \mathrm{ml}$.

The content of phosphorus is approximately equal in gilts and sows. Harvey (1969), quoted a mean of $6.1 \mathrm{mg} / 100 \mathrm{ml}(1.6$ - 9.7), Hewitt (1932) (see Maclean 1972 ), in pigs of different age $4.1-11.7 \mathrm{mg} / 100 \mathrm{ml}$.

Apart from the group of youngest gilts, magnesium levels in gilts corresponded to levels in sows. Some authors, e. g. Albritton (1952), claimed a little higher level $(2.0-4.4 \mathrm{mg} / 100 \mathrm{ml})$, but in young gilts, Meier (1963), achieved results comparable with ours: $2.2 \mathrm{mg} / 100 \mathrm{ml}(1.9-3.2)$.

Regarding blood carbohydrates, our findings are in agreement with literature data: Hewitt (1932) (see Maclean, 1972) pointed out that blood sugar levels considerably varied with different age of pigs. For pigs of 8-9 months, he quoted a range from 55 to $66 \mathrm{mg} / 100 \mathrm{ml}$. Evelett (1935), and, Sampson (1942) 
(see Maclean, 1972), found amounts from 76 to $149 \mathrm{mg} / 100 \mathrm{ml}$. Our results are more align, and, slightly higher in gilts than in sows.

The content of bilirubin is lower in growing gilts than in sows (0.14 and 0.24 $\mathrm{mg} / 100 \mathrm{ml}$, respectively). Similar results obtained Bechyně (1974), who found $0.15 \mathrm{mg} / 100 \mathrm{ml}$ in sows $25-30$ days after insemination, 0.18 and $0.21 \mathrm{mg}$ in the course of pregnancy, and $0.26 \mathrm{mg} / 100 \mathrm{ml}$ in late pregnant sows.

As for cholesterol, our results are comparable with findings reported by $\mathrm{Nach}$ reiner and Ginther (1972) while Bechyně (1974) registered higher levels of cholesterol in pregnant sows.

Vitamin A levels varied in spite of standard feeding. They were lower in the youngest groups I. and III., while in groups II., IV. and V., they corresponded to values found in sows $(20.65 \mathrm{mcg} / 100 \mathrm{ml})$ by Šulc and Bechyně (1976). Kudláč et al. (1976) determined higher levels of vitamin A (39.08) in sows during puerperium. The somewhat lower content of vitamin A in young gilts probably resulted from the higher requirement in the course of growth, the request being not fully covered by the diet.

It is extremely difficult to compare results concerning enzymatic activity with reference data. Methods of determination have been considerably developed and changed in recent years, and consequently very different result have been achieved. Better comparable are increase and decrease of enzymatic activity under definite conditions. Herak et al. (1975), e. g. registered a significantly lower GPT activity during lactation and after weaning than in non-pregnant sows. Alkaline phosphatase also showed decreased activity in the course of lactation and after weaning. In sows coming in heat, about day 6 after weaning, the authors observed decreased activity of alkaline phosphatase and increased activity of acid phosphatase, probably due to the effect of oestrogens. It is notorious that changes in enzymatic activity are induced through the endocrine system. The activity consequently varies in different phases of sexual cycle. The activity of enzymes is also influenced by dietary factors, particularly quantity and quality of proteins and fats.

In piglets, Combs et al. (1959) (see Maclean, 1972), noted decreasing activity of alkaline phosphatase from day 1 to day 7 of their life. Young and Underdahl (1948) (see Maclean, 1972), observed rapid decrease of alkaline phosphatase activity up to day 56 . We are not able to comment these data, since no group of this age was involved in our trial.

In mini-pigs, Maclean (1972), recorded highest activity of alkaline phosphatase after parturition, followed by successive decrease and stabilisation of activity not earlier than at the age of three years. There were decreasing levels (from group II. to III. and IV. to V.), alternated by temporarily increasing values (from group I. to II. and III. to IV.) in our trial. Generally, the activity of all enzymes studied was higher in gilts than in sows in the same farm.

\section{Změny v biochemickém složení krve prasniček během růstu v podmínkách velkochovu}

Stanovili jsme biochemické složení krevního séra od 75 prasniček ve stáří od 4 měsíců do 10 měsíců a tělesné hmotnosti od 30 do $120 \mathrm{~kg}$. Prasničky byly podle stáří a váhy rozděleny do 5 skupin. Ze sledovaných minerálií vykazovaly nejmladší prasničky nejnižší hladinu vápníku $-5,9 \pm 0,61 \mathrm{mg} / 100 \mathrm{ml}$, u fosforu byla naopak u této skupiny nejvyšší hladina $7,1 \pm 0,56 \mathrm{mg} / 100 \mathrm{ml}$. Hladina hořčíku 
byla nejnižší u prasniček I. skupiny a nejvyšší u IV. a V. skupiny. Nejnižší obsah vitaminu A vykazovaly prasničky $I$. skupiny $(16,2 \pm 4,8 \mathrm{mcg} / 100 \mathrm{ml})$, starší prasničky měly hladiny vyšší. Statisticky vysoce významný byl rozdíl mezi I. a V. skupinou. Obsah cukrů byl vyrovnaný v celém období růstu a jen málo se lišil od hladin u dospělých prasnic. Bilirubinu jsme nacházeli poněkud méně u rostoucích prasniček, obsah cholesterolu byl obdobný výskytu u prasnic. Aktivita námi sledovaných enzymů značně kolísala.

\section{Изменения биохимического состава крови свинок в процессе роста в условиях промышленного свиноводства}

Нами был определен биохимический состав кровяной сыворотки 75 свинок в возрасте 4-10 месяцев, весом 30-120 кг. По возрасту и весу свинки были разделены на пять групп. Из числа исследуемых минеральных факторов самые молодые по возрасту свинки содержали самый низкий уровень кальция $-5,9 \pm 0,61$ мг/100 мл, в случае фосфора была у данной группы установлена самая высокая величина $7,1 \pm 0,56$ мг/100 мл. Самый низкий уровень магния наблюдался у первой группы и самый высокий - у четвертой и пятой групп. Самое низкое содержание вытамина А было у свинок первой группы $(16,2 \pm 4,8$ мг/100 мл), у свинок постарше был уровень выше. Статистически весьма существенной была разница между первой и пятой группами. Содержание сахаров в течение процесса роста было разным и лишь немного отличалось от уровня взрослых свиноматок. Билирубин был установлен у менее растущих свинок, содержание холестерола было похоже на содержание в случае свиноматок. Активность исследуемых нами энзимов значительно колебалась.

\section{Acknowledgement}

The technical cooperation of J. Nedbálková and B. Studenčík is appreciated.

\section{References}

ALBRITTON, E. C.: Standard values in blood. Philadelphia 1952.

AZIMOV, G. I. - KRINICIN, D. J. - POPOV, N. F.: Fyziológia hospodárskych zvierat. SNPL, Bratislava 1958.

BECHYNĚ, K.: Obsah některých minerálií, glukózy, bílkovin, lipidů a fermentů v krev. séru prasnic bílého ušlechtilého plemene $\mathrm{v}$ prủběhu březosti. Ref. na stud. vd. konf. VŠV, Brno 1974.

HERAK, M. - MELITA HERAK - KOVAČEVIČ, V. - ŠIMUNDIČ, B. - BENDIĆ - RISTIĆ, G.: Promjene aktivnosti tranzaminaza, te alkalne, kisele fosfataze u krvnom serumu krmača za vrijeme laktacije i poslije odbijanja prasadi. Vet. Arh., 45, 1975: 71-82.

HOMOLKA, J.: Klinická biochemie indikace a interpretace u dospělých a dětí. SZN, Praha 1969. $436 \mathrm{pp}$.

HOMOLKA, J.: Klinické biochemické vyšetřovací metody s použitím mikro- a ultramikroanalýzy. SZN. Praha 1969. 440.

HOŘEJŜ́, J. - FASSATI, M. - JÍCHA, J. - KANDRÁC̆, M. - MAŠEK, K. - MICHALEC, Č. - SLAVÍK, K.: Základy chemického vyšetřování v lékařství. SZdN, Praha 1964. 696.

HOŘEJŠÍ, J.: Základy klinické biochemie ve vnitřním lékařství. SZdN, Praha 1970. 548.

KUDLÁĆ, E. - HRIVNÁK, J. - NEDBÁLKOVÁ, J. - STUDENČÍK, B.: Hladina některých minerálií, glukózy a vitamínu $\mathrm{A} \mathrm{v}$ krev. séru prasnic během puerperia $\mathrm{v}$ podmínkách velkochovu. Vet. Med., Praha 1976, 21, 257-263.

MACLEAN, C. W.: The haematology and serum biochemistry of the sow during the reproductive cycle. Theses, Liverpool 1972. 119. 
MEIER, H.: Clinical biochemistry of domestic animals. New York 1963. $499 \mathrm{pp}$.

NACHREINER, R. F. - GINTHER, O. J.: Gestational and periparturient periods of sows: serum chemical and haematological changes durin gestation. Am. J. vet. Res., 33, 1972: 2215 to 2219.

ROTH - JOSÍFKO - MALÝ - TRČKA: Statistické metody v experimentální medicíně. SZN, Praha, 1962. 592 pp.

ŠULC, J. - BECHYNĚ, K.: Vliv jednorázové aplikace Axetocalu na obsah vitaminu A v krvi a játrech prasnic a jejich plodnost. Ref. na stud. věd. konf. VŠV, Brno 1975.

WIRTH, D.: Grundlagen einer klinischen Hämatologie der Haustiere. Wien u. Innsbruck 1952. 